\title{
Analisis Keterkaitan antara Kecemasan dengan Covid-19 berdasarkan Lukas 21:26
}

Analysis of the Relationship between Anxiety and Covid-19 based on Luke 21:26

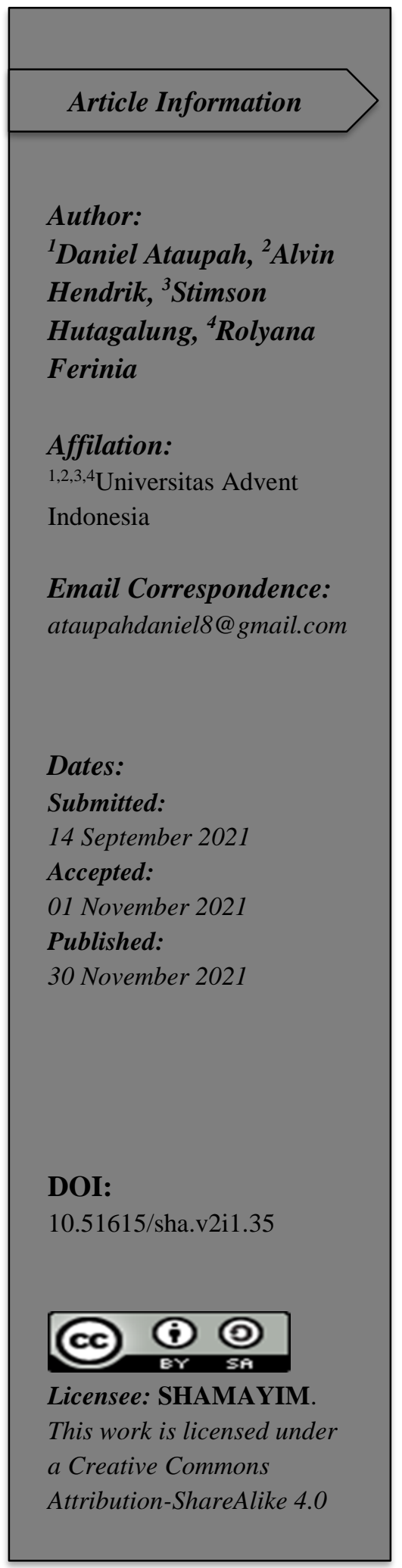

Abstract: Covid-19 is a disease outbreak with terrible effects, where it can cause death. In this case the body will form an immune system to fight the incoming virus. One thing that will affect the immune system is anxiety. So the focus and purpose of the researcher is to show the relationship between anxiety and covid-19 based on the quote of the Lord Jesus in Luke. 21:26. A qualitative method with literature study and hermeneutics will be used in this paper. As a result, fear and anxiety are currently being experienced by everyone because of the covid-19 pandemic which can be interpreted as a pestilence and as a sign of the end of time. Although this is not a sign of the end times that can be measured with certainty, it is psychologically and emotionally disturbed and exacerbated by the news that is presented on the internet and social media in excess.

Keywords: Anxiety, Covid-19, Luke 21:26, Immune

Abstrak: Covid-19 merupakan sebuah wabah penyakit dengan efek yang mengerikan, di mana hal ini dapat menyebabkan kematian. Dalam hal ini tubuh akan membentuk sistem kekebalan tubuh untuk melawan virus yang masuk. Satu hal yang mempengaruhi akan sistem kerja kekebalan tubuh adalah kecemasan. Maka fokus dan tujuan dari penelitian ini ingin menunjukkan korelasi antara kecemasan dengan covid-19 berdasarkan perkataan Tuhan Yesus dalam Lukas. 21:26. Sebuah metode kualitatif dengan teknik studi pustaka dan hermeneutika akan dipergunakan dalam penulisan ini. Hasilnya, ketakutan dan kecemasan saat ini sedang dialami oleh setiap orang karena pandemi covid-19 yang dapat diinterpretasikan sebagai penyakit sampar dan sebagai tanda akhir zaman. Meskipun ini bukanlah tanda akhir zaman yang dapat diukur kepastiannya, tetapi memang secara psikologis dan emosional pikiran manusia menjadi terganggu dan diperparah dengan berita-berita yang disajikan di internet dan media sosial secara berlebihan.

Kata Kunci: Kecemasan, Covid-19, Lukas 21:26, Imun 


\section{Pendahuluan}

Virus SARS-CoV-2 menyebabkan suatu bencana melanda secara global seluruh dunia, sebab virus SARS-CoV-2 menyebabkan penyakit yang sangat akut dan sangat membahayakan yang terkenal dengan Covid-19. Penyakit Covid-19 awal mulanya diketemukan di kota Wuhan, China. Dengan cepat penyakit ini menyebar dan banyak menyebabkan berbagai dampak termasuk merenggut banyak jiwa (Maryani et al., 2020).

WHO menetapkan Covid-19 sebagai pandemi pada tanggal 30 Januari 2020, dalam hal ini dimengerti sebagai sebuah kedaruratan dalam hal kesehatan yang melanda seluruh dunia termasuk juga melanda di Indonesia (Putri, 2020). Sejak ditetapkan sebagai pandemi global, kasus Covid-19 semakin terus meningkat, baik secara global maupun tingkat nasional Indonesia. Menurut data yang diperoleh dari situs resmi satgas Covid-19 nasional Indonesia per 16 Agustus 2021 didapat data kasus Covid-19 telah menyebar di 223 negara di dunia dengan data terkonfirmasi positif berjumlah 205.338.159, sementara data yang meninggal berjumlah 4.333.094. Secara nasional kasus yang terkonfirmasi positif berjumlah 3.854.354, yang telah sembuh berjumlah 3.351.959 dan yang meninggal sejumlah 117.588 (Satgas Covid-19, 2021).

Covid-19 merupakan penyakit menular yang menmginfeksi sistem pernafasan atas maupun bawah, di mana penularannya dapat ditularkan melalui cipratan air liur yang jatuh dan yang keluar pada saat berbicara, bisa juga saat batuk maupun juga saat bersin (Meri et al., 2020). Gejala khas yang ditimbulkan apabila seseorang terinfeksi Covid-19 adalah batuk, demam, flu, sakit tenggorokan, gangguan pernafasan, kelelahan, sakit kepala dan gangguan pencernaan (Karo, 2020). Oleh sebab itu, maka usaha-usaha preventif perlu dilakukan untuk pencegahan penularan yang lebih luas lagi. Sebagaian upaya pencegahan dapat dilakukan dengan cara menerapkan disiplin kesehatan diri, rajin untuk mencuci tangan, selalu menjaga jarak dan konsisten untuk memakai masker. Dalam usaha pencegahan dengan kapasitas jumlah masa yang banyak, pemerintah menerapkan upaya pembatasan sosial berskala besar (PSBB) (Satgas Covid-19, 2021).

Wabah yang disebabkan Covid-19 tidak diketahui kapan akan berakhir. Korban jiwa banyak berjatuhan di mana-mana, rumah sakit - rumah sakit penuh, hal ini menimbulkan suatu kelelahan baik secara fisik maupun mental. Menurut penelitian yang dilakukan oleh Sardono, Hermiawan menyatakan bahwa wabah Covid-19 ini membuat banyak orang menjadi putus asa, tidak pastinya situasi dan lebih lanjut disebutkan dalam penelitian tersebut bahwa wabah ini menimbulkan sebuah ketakutan dan kecemasan yang mendalam (Sardono et al., 2020). Demikian juga yang dialami oleh orang yang terinfeksi virus covid-19, orang tersebut akan mengalami kecemasan yang sangat tinggi.

Jiwa akan terganggu sehingga mengalami berbagai masalah gangguan kejiwaan yaitu selain cemas juga mengalami ketakutan, depresi, stress, panik, sedih, ketakutan, emosi yang tidak terkendali (Juli Andri, Padila, 2021). Di mana pengertian dari cemas merupakan sebuah tanggapan individu terhadap suatu situasi yang tidak nyaman atau menyenangkan sehingga menimbulkan perasaan atau suasana hati yang tidak menentu dan ketidak berdayaan (Setyawan, 2017). Padahal perasaan cemas yang terus menerus akan sangat berpengaruh dan bisa menurunkan imunitas. Pada saat seseorang merasa dirinya mulai cemas, antibodi yang ada di dalam tubuh akan lambat untuk berproduksi sehingga membuat tubuh kita menjadi mudah lelah, lemah dan lebih jauh lagi memudahkan virus masuk sehingga mudah terkena infeksi, termasuk infeksi virus Corona (Suryani, 2020). Tanda yang khas ketika seseorang sedang mengalami kecemasan ditandai dengan meningkatnya tekanan darah, meningkatnya denyut nadi, dan meningkatnya pernafasan (Arini et al., 2017). Atas dasar pernyataan dalam penelitian inilah maka muncul pertanyaan, apakah ada dampak kecemasan yang signifikan terhadap tubuh di tengah-tengah situasi pandemi yang sedang melanda? Berdasarkan hal yang sudah dipaparkan, tujuan dalam penelitian ini adalah untuk mencari keterkaitan 
antara kecemasan dengan Covid-19 yang didasarkan perkataan Tuhan Yesus tentang kata cemas dalam Lukas 21:26.

\section{Metodologi Penelitian}

Penelitian ilmiah ini memakai metodologi kualitatif (Sudarmanto et al., 2021), dengan analisis interpretatif menggunakan studi literatur. Dalam penelitian ini, Lukas 21:26 dianalisis secara interpretatif dengan fokus kepada kecemasan dengan menghubungkannya dengan tanda kedatangan Yesus. Kemudian, analisis ini akan menjelaskan implikasinya dengan kondisi zaman saat ini, yaitu pandemi covid-19.

\section{Hasil dan Pembahasan}

Teks Lukas. 21:26 tentang kecemasan yang mengakibatkan kematian dilihat dari sisi terjemahan dan bahasa asal aslinya kitab ditulis yaitu bahasa Yunani di dapati bahwa kecemasan dapat dimengerti sebagai sebuah ketakutan dan khawatir yang sangat dalam.

Sementara mati dapat dimengerti sebagai keterpisahan anatara nafas hidup dengan tubuh, gagal jantung dan nafas yang berat. Sehingga dapat dimengerti bahwa kecemasan akan dapat mengakibatkan sesak nafas dan gagal jantung yang bisa mengakibatkan kematian atau keterpisahan nafas (Meyers, 2021). Ayat alkitab ini digunakan sebagai dasar adalah sistem hermeneutic empirtissme - positivisme yaitu sistem penafsiran yang dalam penafsirannya tidak ada keterkaitan antara teks dengan penggagas, akan tetapi adanya keterkaitan dan pengaruh dari sintaksis dan semantik bahasa yang digunakan (Fitria, 2016).

Kecemasan merupakan sebuah suasana hati yang berupa ketakutan dan kekuatiran yang dapat dilihat dalam bentuk rangkaian gejala yang muncul dan dilihat secara fisik maupun mental, maka pendekatan yang dilakukan dengan pendekatan psikologi yang sangat terkait erat berhubungan dengan bidang keagamaan (Tobing et al., 2017). Kecemasan sangat berpengaruh terhadap tingkat imun dengan dasar ilmiah bahwa ketika orang menghadapi rasa cemas, maka tubuh akan mengeluarkan zat kimia yang akan memacu jantung bekerja dengan cepat dan membuat nafas menjadi cepat. Apabila rasa cemas yang berlebihan ini terus menerus dibiarkan berkelanjutan, maka zat-zat kimia ini akan mengganggu sistem kerja imun tubuh, sehingga mengakibatkan imun tubuh akan menurun. Apabila sistem imun menurun maka tidak akan dapat melawan virus corona yang masuk dan menginfeksi tubuh (Eko Meinarno, Maya Khairani, 2020). Akibatnya akan membuat pneumonia ataupun sistem organ lain dan lebih fatal akan bisa mengakibatkan kematian. Sehingga dalam kasus ini terlihat jelas hubungan kecemasan dengan kematian baik dari segi alkitabiah maupun ilmiah dengan kasus covid-19.

\section{Lukas 21}

Injil Lukas pasal 21 terdiri dari enam perikop yang membentuk sebuah alur cerita yang saling berkesinambungan. Perikop pertama dari kitab Lukas 21 sebagai awal dari pasal ini diawali dengan kisah persembahan seorang janda miskin yang terdapat dalam Lukas. 21:1-4. Perikop ke dua dari pasal ini yang terdiri dari dua ayat berkisah tentang Bait Allah yang akan diruntuhkan (Lukas. 21:5-6). Perikop ke tiga berisi tentang permulaan penderitaan, yaitu informasi tentang awal peristiwa-peristiwa peristiwa akhir zaman (Lukas. 21:7-19). Perikop ke empat tentang runtuhnya Yerusalem (Lukas. 21:20-24), perikop ke lima bercerita tentang kedatangan anak manusia dan perumpaan tentang pohon ara (Lukas. 21:25-33), dan perikop terakhir tentang nasihat supaya berjaga-jaga (Lukas. 21:34-38). 
Dalam Lukas pasal 21 bila diperhatikan berdasarkan perikop-perikop yang tersusun di dalamnya, secara garis besar dapat dilihat bahwa Injil Lukas pasal 21 berisi hal-hal yang berkaitan mengenai akhir zaman, di mana meliputi tanda-tanda akhir zaman dan nasehat-nasehat mengenai apa yang harus dilakukan bagi umat-umat Tuhan untuk menghadapi hari besar yaitu akhir zaman yang ditandai dengan kedatangan Tuhan Yesus yang kedua kali.

Injil Lukas pasal 21, secara khusus ayat 5 sampai dengan ayat 38 bersifat apokaliptis yaitu pengungkapan sesuatu yang akan terjadi di masa depan yang masih tersembunyi, dalam konteks ini, secara khusus Lukas 21 berbicara tentang hari Tuhan dengan berbagai tanda-tandanya (Ambesa, 2020). Pernyataan ini diperkuat dengan pertanyaan para murid Yesus mengenai hal-hal yang berkaitan dengan hari Tuhan tersebut, "Dan murid-murid bertanya kepada Yesus, katanya: "Guru, bilamanakah itu akan terjadi? Dan apakah tandanya, kalau itu akan terjadi?" (Lukas. 21:7).

Menurut Injil Lukas pasal 21 ada tanda-tanda yang mendahului akan peristiwa hari Tuhan datang, yaitu: akan ada orang yang memakai nama Yesus dan mengaku sebagai Yesus (Lukas. 21:8), adanya peperangan dan pemberontakan yaitu peperangan antar bangsa maupun kerajaan (Lukas. 21:9-10), adanya bencana alam gempa bumi yang dasyat (Lukas. 21:11), adanya wabah penyakit (sampar) dan kelaparan (Lukas. 21:11), tanda-tanda di langit (Lukas. 21:11), Penganiayaan orang percaya (Lukas. 21:12).

Pelajaran dari pohon ara diungkapakan Yesus di akhir dari pembelajaran yang diberikan kepada murid-muridNya mengenai hal hari Tuhan yang akan datang. Apabila sudah mulai bertunas maka akan memasuki musim panas, demikianlah ketika tanda-tanda yang dinyatakan Yesus sudah terjadi, itu artinya bahwa hari Tuhan sudah dekat. "Apabila kamu melihat pohon-pohon itu sudah bertunas, kamu tahu dengan sendirinya bahwa musim panas sudah dekat. Demikian juga, jika kamu melihat hal-hal itu terjadi, ketahuilah, bahwa Kerajaan Allah sudah dekat" (Lukas. 21:30-31).

\section{Penggenapan}

Lukas 21:8 memberi keterangan bahwa akan ada orang yang datang memakai nama Yesus dan mengaku bahwa di adalah Yesus. Salah satu orang yang pernah menyatakan dirinya Yesus Kristus adalah Alvaro Theiss. Ia adalah seorang berkewarganegaraan Brazil dan ia percaya bahwa ia adalah reinkarnasi Yesus yang memiliki pengikut yang cukup banyak yang tersebar di dunia dengan nama gereja Soust (Sutomonaio, 2017).

Sindonews pada hari Senin, 29 Juni 2020 memberitakan bahwa ada 7 perang terbesar di dunia, yaitu perang seratus tahun yang merupakan perang antara Inggris dan Perancis pada tahun 1337-1453, Perang salib, Perang Napoleon, Perang Dunia I, Perang Dunia II, Perang Dingin dan terakhir adalah konflik antara Israel dan palestina (Wahyono, 2020). Peristiwa peperangan di dunia ini menggenapi akan perkataan Yesus di Lukas. 21:9-10.

Berita di harian Kompas pada 14 Februari 2021 meberitakan ada sepuluh gempa bumi yang sangat dasyat di dunia, salah satunya adalah gempa bumi yang pernah melanda di Indonesia, yaitu tsunami yang menerpa Aceh pada tahun 26 Desember 2004 dengan menewaskan 227. 900 orang sebab gempa bumi ini berkekuatan 9,1 magnitudo. Hal gempa seperti ini pernah dinyatakan Yesus sebagai tanda-tanda akan datangnya hari Tuhan di Lukas 21.

Harian Merdeka yang terbit hari Jumat 12 April 2013 memberitakan mengenai lima kelaparan hebat yang melanda di dunia yaitu kelaparan di China pada tahun 1958-1962, kelaparan India 1783, kelaparan Uni Sovyet 1932-1933, kelaparan Bengali 1770 dan 1943, serta Kelaparan korea Utara. Atas peristiwa ini puluhan juta orang meninggal sebab kelaparan (Maharani, 2013). 


\section{Tanda Wabah Sampar}

Salah satu tanda akan datangnya hari Tuhan yang disebutkan dalam kitab Lukas 21 adalah adanya penyakit sampar. Kata aslinya dalam alkitab adalah גoupó (loimos) yang berarti wabah penyakit. Dengan demikian bila dilihat dari makna arti yang di dapat dari bahasa aslinya sampar berarti wabah penyakit.

Alkitab versi terjemahan Indonesia Literal Translation 3 menyebutkan bahwa sampar adalah wabah, "juga akan terjadi gempa bumi yang dahsyat di berbagai tempat, dan kelaparan-kelaparan, dan wabahwabah penyakit, juga akan terjadi hal-hal yang menakutkan dan tanda-tanda yang dahsyat dari langit" (Lukas. 21:11, ILT3).

Virus Corona yang juga dikenal dengan covid-19 telah ditetapkan oleh World Health Organization (WHO) sebagai pandemi atau wabah, sebab penyakit ini telah melanda secara global yang berskala besar bukan lagi peristiwa lokal (Hutagalung, 2020). Dengan demikian bahwa wabah penyakit covid-19 ini turut menjadi penggenapan dan penegasan akan tanda-tanda akan datangnya hari Tuhan di akhir zaman sesuai denga kitab Lukas 21.

Salah satu dampak dari pandemi covid-19 adalah krisis psikologis yang salah satunya adalah kecemasan. Kecemasan yang terjadi meliputi beberapa aspek yaitu fisik, kognitif, emosi, dan perilaku. Hal ini dapat dilihat dari gejala yang muncul antara lain sering sakit kepala dan jantung bedebar-debar tidak seperti biasanya (Fakhriyani et al., 2021). Kecemasan akibat pandemi yang melanda sebagai salah satu dari tanda akan datangnya hari Tuhan pada zaman akhir dan juga tanda-tanda yang lain pernah disampaikan oleh Tuhan Yesus kepada murid-muridNya di Lukas 21:26.

\section{Perikop Kedatangan Anak Manusia dan Pohon Ara (Lukas 21:25-33)}

Perikop ini tentang kedatangan Anak Manusia dan perumpamaan pohon ara sangat terkait dengan perikop sebelumnya dan merupakan satu rangkaian cerita di mana Yesus sedang menjelaskan akan tandatanda kedatangan Anak Manusia. Penekanan perikop ini terlihat di ayat yang ke 28 dari kitab Lukas 21, "Apabila semuanya itu mulai terjadi, bangkitlah dan angkatlah mukamu, sebab penyelamatanmu sudah dekat." Ayat ini menekankan tentang menganalisa penggenapan nubuat tentang akhir zaman yang mana nubuat itu sudah disampaikan oleh Yesus di perikop dan ayat-ayat sebelumnya dan mengenai tanda-tanda akhir zaman sudah dijelaskan dipembahasan sebelumnya.

Untuk memperjelas dalam menganalisa waktu penggenapan nubuat akan kedatangan Anak Manusia, Yesus memberikan sebuah pelajaran dari siklus alam yang terjadi pada pohon ara. "Apabila kamu melihat pohon-pohon itu sudah bertunas, kamu tahu dengan sendirinya bahwa musim panas sudah dekat. Demikian juga, jika kamu melihat hal-hal itu terjadi, ketahuilah, bahwa Kerajaan Allah sudah dekat" (Lukas. 21:3031). Senada dengan hal ini, Lee berpendapat bahwa Pohon ara yang diungkapkan Yesus adalah tanda untuk orang-orang yang beriman pada akhir zaman ini (Lee, 2020).

Dalam hal menganalisa penggenapan nubuatan, Simon dan kawan-kawan menyatakan bahwa wabah covid-19 merupakan sebuah bagian dari penggenapan nubuat alkitab mengenai akhir zaman. Wabah covid19 memberi isyarat bahwa situasi yang terjadi saat ini berada pada fase akhir zaman (Simon et al., 2021). Dalam fase ini banyak orang akan mengalami kecemasan akibat peristiwa-peristiwa yang telah terjadi seperti yang telah dinyatakan oleh Yesus dalam Lukas 21:26. 


\section{Lukas 21:26}

Teks Lukas 21:26 “Orang akan mati ketakutan karena kecemasan berhubung dengan segala apa yang menimpa bumi ini, sebab kuasa-kuasa langit akan goncang." Dalam teks ini memuat hubungan sebab akibat yaitu adanya sebuah kematian yang disebabkan oleh kecemasan. Kecemasan timbul atau muncul oleh sebab adanya peristiwa-peristiwa yang akan terjadi pada bumi ini sehubungan dengan peristiwa kedatangan Tuhan Yesus yang kedua kali yang telah dijelaskan pada perikop sebelumnya.

Kecemasan itu terjadi ketika orang-orang di zaman akhir melihat situasi yang tidak menentu dan banyak kekacauan sehingga menimbulkan kecemasan dan ketakutan yang mendalam, sehingga orang bisa mati oleh karena pikiran yang selalu cemas, pikiran yang dipenuhi dengan ketakutan. Konteks kecemasan yang ada di dalam Lukas. 21:26 mirip dengan kecemasan yang terjadi saat penelitian ini dibuat, konsep yang terbentuk dan terbangun dari kecemasan mengenai suatu peristiwa yang menerpa seluruh dunia, yaitu pandemi Covid-19 sehingga menimbulkan sebuah ketakutan. Reaksi dan respon tubuh sama seperti yang terjadi dalam Lukas. 21:26.

Menurut bahasa Yunani, bahasa asli Alkitab di mana ayat ini dituliskan, kata kecemasan yang

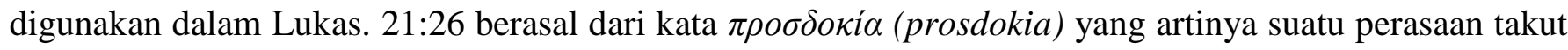

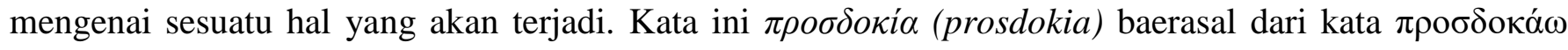
(prosdokaō) dengan arti dasar melihat atau memperhatikan dan mengantisipasi (Meyers, 2021). Arti secara keseluruhan dapat diartikan sebagai suatu keadaan sedang menunggu, memperhatikan sesuatu hal yang akan terjadi dengan pikiran yang penuh kekhawatiran dan ketakutan.

Kata takut yang digunakan dalam Lukas. 21:26, kata yang muncul sebelum kecemasan menggunakan

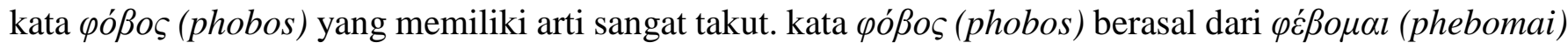
yang memiliki arti alrm (Meyers, 2021) Pengertian yang didapat secara luas dari bahasa aslinya, adalah suatu perasaan takut yang sangat mendalam mengenai sesuatu hal yang menimpa dalam diri seseorang dan itu merupakan sebuah alrm dalam tubuh yang menandakan ada reaksi ketakutan yang sangat dalam diri seseorang tersebut. Senada dengan pengertian dari bahasa asli Alkitab mengenai "alrm," Freud memberi penjelasan bahwa kecemasan merupakan sebuah fungsi dari ego untuk memberikan sebuah peringatan mengenai adanya sebuah bahaya yang harus segera di tanggapi secara adaptif menurut bahaya yang akan datang (Sihombing \& Rundjan, 2019).

Фóßos (phobos) hanya dipakai oleh sebab adanya suatu kepanikan, perasaan ketakutan pada saat

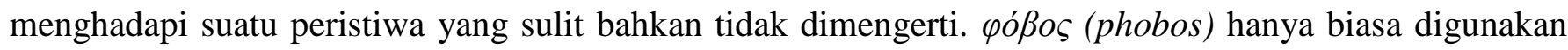
atau dipakai ketika suasana yang mau diterangkan mengalami kecemasan (Tadung, 2020). Menurut orang

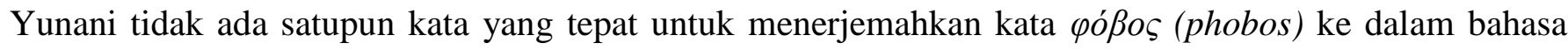

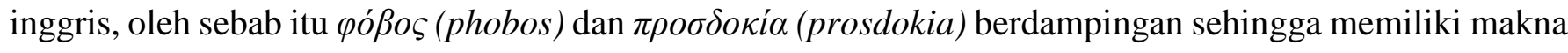
yang mirip, saling melengkapi satu sama lain yang dominan berhubungan dengan kecemasan (Nagy, 2010). 
Kata cemas menurut terjemahan Alkitab dalam berbagai terjemahan Alkitab:

Tabel 1. Kata Cemas menurut terjemahan Alkitab

\begin{tabular}{ll}
\hline Kitab Terjemahan & Lukas 21:26 \\
\hline Terjemahan Baru: & "Orang akan mati ketakutan karena kecemasan berhubung dengan segala \\
& apa yang menimpa bumi ini, sebab kuasa-kuasa langit akan goncang."? \\
\hline Bahasa Jawa: & $\begin{array}{l}\text { "Wong-wong bakal padha semaput dening giris amarga kuwatir (kuatir) } \\
\text { marang apa kang bakal nekani jagad; amarga kabeh panguwasaning langit } \\
\text { bakal gonjing." }\end{array}$ \\
\hline Bahasa Sunda: & "Jelema-jelema kalabur pangacianana awahing ku sieun (takut) ku anu \\
& bakal tumiba ka ieu bumi, sabab kakuatan-kakuatan langit genjlong, jalanna \\
& nyarimpang." \\
\hline Terjemahan & "Orang-orang akan sangat ketakutan karena kuatir terhadap semua yang \\
Sederhana & terjadi di atas bumi ini, karena para penguasa rohani yang mengatur benda- \\
Indonesia: & benda di langit akan menjadi kacau-balau." \\
\hline
\end{tabular}

Jadi, kata cemas dalam teks Lukas. 21:26 adalah suatu perasaan dan pikiran yang dipenuhi kekuatiran dan ketakutan yang sangat mengenai sesuatu yang akan terjadi di bumi ini pada saat akhir zaman dengan tanda-tanda yang dasyat.

Dilihat dari sudut pandang asal kata dari bahasa Yunani yaitu bahasa asli dari kitab perjanjian baru

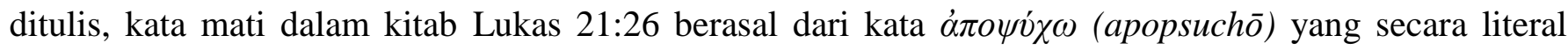
memiliki arti pertama keluarnya nafas kehidupan; kedua. Pingsan; ketiga. Gagal jantung (Meyers, 2021). Dalam beberapa terjemahan Alkitab, ada yang menggunakan kata mati dan ada juga yang memakai kata pingsan. Dalam Alkitab terjemahan Kings James Version menggunakan kata gagal jantung.

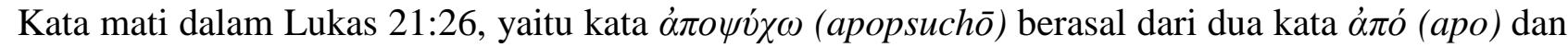
$\psi v ́ \chi \omega(p s u c h \overline{)})$. Kata $\alpha \pi \delta ́$ (apo) yang berfungsi atau digunakan sebagai awalan memiliki arti untuk menunjukkan pemisahan sesuatu dari bagian utamanya. Sementara kata $\psi v ́ \chi \omega ~(p s u c h \bar{o})$ memiliki pengertian bernafas dengan berat atau sesak nafas yang berat (Meyers, 2021) Dari dua kata ini, kata mati dalam Lukas. 21:26 memberikan pengertian bahwa pemisahan atau penghentian proses bernafas yang dimulai dengan susah bernafas. Kematian memiliki pengertian sebagai berhentinya nafas hidup atau proses bernafas dari rangkaian kehidupan biologis manusia (Andrianta et al., 2020).

Dilihat dari segi ilmu pengetahuan modern dengan penelitian yang akurat membuktikan bahwa perasaan cemas yang terjadi pada seseorang akan sangat mempengaruhi jantung manusia. Yang terjadi dalam tubuh apabila mengalami kecemasan maka akan membebani kerja jantung, efek yang ditimbulkan dari hal ini maka akan terjadi sesak nafas, dada terasa nyeri, frekuensi angin meningkat sehingga stabilitas angina menjadi buruk (Nuraeni \& Mirwanti, 2017).

\section{Cemas Di Masa Pandemi Covid-19}

Berdasarkan keterangan dalam Kamus Besar Bahasa Indonesia (KBBI), kata cemas mempunyai pengertian yang dijabarkan dalam beberapa hal, yaitu: suatu perasaan hati yang tidak tentram yang disebabkan oleh karena ketakutan ataupun khawatir; gelisah (Ebta Setiawan, 2021). Dengan demikian dapat dipahami dari arti kata cemas sesuai dengan Kamus Besar Bahasa Indonesia online adalah adanya sebuah 
kegelisahan sebagai akibat hati yang tidak tentram oleh karena dipenuhi rasa khawatir dan ketakutan dalam diri seseorang tersebut.

Kecemasan memiliki tiga aspek yang kemudian dapat dilihat dari gejala yang ditimbulkan, yaitu aspek fisik yang ditandai dengan mulut keras dan kering, perut terasa mual, dan munculnya keringat yang bukan disebabkan oleh aktivitas fisik. Yang kedua adalah aspek emosional yang ditandai dengan gejala panik dan perasaan takut. Aspek yang ketiga adalah kognitif dimana hal ini diwujudkan dengan gejala kognitif seperti sulit untuk fokus, ingatan terganggu, mengalami kebingungan, dan gejala-gejala lainnya yang serupa (Chodijah et al., 2020)

Imunitas merupakan sebuah kemampuan yang dimiliki tubuh dalam usaha untuk melawan organisme, virus, racun, yang memiliki kecenderungan untuk merusak organ ataupun jaringan tubuh (Syarifuddin, 2019). Sistem imunitas ini terwujud dalam bentuk sel-sel dengan memiliki fungsi sebagai pasukan tentara di dalam tubuh untuk memerangi dan membersihkan benda-benda asing yang telah masuk di dalam tubuh manusia tersebut (Aidah, 2020).

Pikiran yang yang berbeban sangat berpengaruh terhadap sistem imun manusia. Tingkat stres yang tidak terkendali akan melemahkan sistem imun tubuh manusia, sebaliknya tingkat stress yang dapat diatasi dengan baik akan mampu menaikan sistem imun tubuh (Tanjung Subrata et al., 2020). Stres terjadi oleh sebab kecemasan yang terus menerus yang tidak diatasi. Kecemasan yang terus menerus akan menyebabkan stress atau depresi, yang akan berdampak secara langsung terhadap imun tubuh, sehingga membuat imun tubuh turun (Eko Meinarno, Maya Khairani, 2020). Kecemasan sangat berpengaruh terhadap turunnya imun tubuh.

Pada saat manusia mengalami kecemasan, sistem tubuh akan mengeluarkan bahan kimia serta hormon adrenalin. Apabila ini dalam jangka pendek tidak menjadi masalah, namun ketika situasi ini terus berkelanjutan maka akan melemahkan tubuh, sistem imun akan terganggu sehingga rentan untuk terinfeksi virus. Selain itu kecemasan akan membuat nafas menjadi dangkal dan cepat, sehingga sangat mempengaruhi sistem pernafasan (Makarim, 2021).

Secara rinci Nuraeni dan Mirwanti memberi penjelasan keterkaitan antara kecemasan dengan menurunnya imun tubuh sebagai berikut, apabila seseorang merasa cemas maka akan menstimulasi amigdala untuk selanjutnya akan mempengaruhi sistem kerja hormonal yang berada pada hipotalamus dan mempengaruhi hormone CRF keluar. Hormone inilah yang akhirnya mempengaruhi hipofisi mengeluarkan hormon yang lainnya yaitu ACTH. ACTH ini kemudian merangsang kelenjar dalam tubuh yaitu kelenjar adrenal untuk mengeluarkan hormone kortisol. Kortisol yang mengalami peningkatan akan menekan sistem kekebalan tubuh atau imun, sehingga apabila manusia mengalami kecemasan akan rentan untuk terinfeksi (Nuraeni \& Mirwanti, 2017).

Sudah jelas bahwa virus corona merupakan penyebab dari penyakit Covid-19. Apabila seseorang terpapar atau terinfeksi virus yang bernama corona ini maka akan mengalami gangguan-gangguan pada sistem pernapasan, dimulai dari beberapa gejala ringan seperti flu, bahkan sampai pada gangguan infeksi paru-paru yang akut seperti pneumonia, lebih jauh lagi bisa mengakibatkan kematian (Yuansari Octaviana Kansil, 2021).

Sesuai dengan pembahasan sebelumnya, menyatakan bahwa, kecemasan yang terus menerus, akan mengakibatkan sistem pertahanan tubuh menjadi lemah, namun pada saat yang sama, imun tubuh sangat diperlukan sekali sebagai pertahanan tubuh manusia dalam menghadapi berbagai benda asing yang masuk dalam tubuh manusia, dalam hal ini adalah juga virus covid-19. Bilamana situasi dan kondisi ini terjadi 
secara terus tanpa henti, maka tubuh tidak akan bisa melawan virus corona yang menginfeksi sehingga bisa menimbulkan gejala yang berat bahkan bisa mengakibatkan kematian.

\section{Korelasi Kecemasan dengan Lukas 21:26}

Suasana hati yang penuh kecemasan, sesuai dengan pembahasan sebelumnya menimbulkan suatu masalah yang sangat serius, secara khusus yang berhubungan dengan situasi pandemi Covid-19. Sesuai dengan pembahasan sebelumnya kecemasan yang terus menerus akan menurunkan imun tubuh dengan demikian rentan terhadap infeksi dan juga mempengaruhi sistem jantung, oleh sebab itu membutuhkan penanganganan secara serius dengan management yang baik.

Sebagai orang beriman, maka hal pertama yang harus dilakukan adalah percaya pada Tuhan didalam doa, bahwa Tuhan tidak akan meninggalkan kita. 1 Petrus. 5:7 "Serahkanlah segala kekuatiranmu kepadaNya, sebab Ia yang memelihara kamu." Filipi. 4:13 "Segala perkara dapat kutanggung di dalam Dia yang memberi kekuatan kepadaku."

Upaya mengatasi kecemasan atau masalah psikososial salah satunya dapat dilakukan dengan memakai faktor spiritual. Hal seperti ini pernah diteliti di Brazil dan hasilnya menunjukkan sesuatu yang baik, yaitu terapi spiritual yang dikenal dengan spiritual healing dapat membuat turunnya tingkat stress dan lebih jauh lagi dapat menaikkan saturasi perifer oxyhemoglobin. Peneilitian yang lain yang dilakukan di sebuah rumah sakit yang berada di Bandung menunjukkan bahwa ada korelasi positif depresi akan menurun apabila tingkat kesejahteraan spiritual dalam kondisi yang baik (Nuraeni \& Mirwanti, 2017).

Menurut Asrori bahwa terapi kognitif sangat mempengaruhi tingkat kecemasan, dimana pikiran negatif yang ada pada diri seseorang diubah menjadi suatu pemikiran yang bersifat positif. Memiliki pemikiran yang positif membuat seseorang meiliki perasaan lega dan nyaman, sehingga seseorang yang sebelumnya memiliki perasaan cemas akan menjadi lebih percaya diri pada saat menghadapi kondisi yang dicemaskan sebelumnya (Asrori, 2015). Nasehat firman Tuhan melalui hamba-Nya Rasul Paulus dalam Filp. 4:8 "Jadi akhirnya, saudara-saudara, semua yang benar, semua yang mulia, semua yang adil, semua yang suci, semua yang manis, semua yang sedap didengar, semua yang disebut kebajikan dan patut dipuji, pikirkanlah semuanya itu." Penelitian lain yang dilakukan oleh Santoso juga memberikan gambaran senada mengenai pengaruh pola pikir, di mana pengaruh perubahan pola pikir diperlukan untuk dapat mengembalikan dari perilaku yang menyimpang (Santoso, 2021), dalam hal ini adalah kecemasan.

Membatasi diri terhadap informasi-informasi yang dapat menyebabkan kecemasan (Muslim, 2020), dalam kasus ini, mengenai Covid-19, maka harus membatasi diri dengan berita-berita hoaks mengenai Covid-19. Berita-berita yang tidak benar, berita-berita yang negatif yang belum tentu kebenaran akan membuat perasaan cemas yang berlebihan.

\section{Korelasi Lukas 21:26 dengan Situasi Covid-19}

Lukas.21:26 berada pada suatu keterangan yang menjelaskan mengenai rangkaian peristiwa kedatangan Tuhan Yesus yang kedua kali atau akhir zaman. Lukas. 21:26 secara khusus memberikan keterangan tentang kecemasan oleh sebab peristiwa - peristiwa besar yang akan menimpa bumi saat menjelang akhir zaman, terkesan menawarkan kesusahan, kebingungan, ketakutan dan firasat yang menyertai akhir zaman.

Istilah pandemi di dalam alkitab disebut sebagai "sampar," dalam istilah Indonesia disebut sebagai wabah atau penyakit menular yang dapat dengan cepat menyebar dan menularkan kepada orang-orang yang 
ada disekitarnya. Lukas. 21:11 memberikan keterangan bahwa penyakit sampar atau wabah akan menerpa bumi ini sebelum kedatangan Tuhan Yesus yang kedua kali. Covid-19 adalah virus yang mewabah dan kemudian menjadi pandemi global. Covid-19 merupakan penyakit sampar yang muncul pada zaman ini menjadi tanda sesuai dengan Lukas 21:11 (Sumakul, 2020).

Menurut Ambesa bahwa teks Lukas 21:5 dan selanjutnya sampai 38 bergenre apokaliptis (Ambesa, 2020). Dari keterangan ini maka terlihat dengan jelas ketika membaca konteks Lukas 21 ini antar ayat dan perikop merupakan suatu keterkaitan satu dengan yang lain serta merupakan satu cerita. Hal ini terlihat dengan jelas ketika murid Yesus dalam ayat yang ke 7 kitab Lukas 21 menanyakan tentang tanda-tandanya, "Dan murid-murid bertanya kepada Yesus, katanya: "Guru, bilamanakah itu akan terjadi? Dan apakah tandanya, kalau itu akan terjadi?" (Lukas. 21:7). Salah satu penjelasan Yesus terlihat dalam Lukas. 21:11 "dan akan terjadi gempa bumi yang dahsyat dan di berbagai tempat akan ada penyakit sampar dan kelaparan, dan akan terjadi juga hal-hal yang mengejutkan dan tanda-tanda yang dahsyat dari langit." Menurut ayat ini akan ada penyakit sampar yang adalah wabah dan covid-19 adalah termasuk wabah sesuai keterangan sebelumnya.

Lukas. 21:26, "Orang akan mati ketakutan karena kecemasan berhubung dengan segala apa yang menimpa bumi ini, sebab kuasa-kuasa langit akan goncang." Teks ini memberikan keterangan mengenai kecemasan terhadap peristiwa yang akan terjadi pada menjelang akhir zaman, dan peristiwa itu salah satunya adalah penyakit sampar yaitu penyakit yang menular dan menjadi wabah maka kecemasan itu juga berlaku dan sedang digenapi mengenai nubuatan kecemasan melalui wabah penyakit covid-19 yang sedang melanda. Jadi, situasi yang dibicarakan dalam Lukas. 21:26 mengenai kecemasan akan hal-hal yang menimpa di bumi, sinkron dengan situasi yang terjadi saat wabah covid-19 ini terjadi, yaitu penuh dengan kecemasan. Meskipun ini bukanlah tanda akhir zaman yang dapat diukur kepastiannya, tetapi secara psikologis dan emosional pikiran manusia menjadi terganggu. Hal ini diperparah dengan berita-berita yang disajikan di internet dan media sosial dengan pernyataan-pernyataan yang berlebihan memberikan tekanan emosional lain dalam diri manusia.

\section{Implikasi Lukas 21:26 Terhadap Kecemasan Orang Percaya}

Secara historis Lukas.21:26 sedang menerangkan situasi zaman akhir menuju akhir zaman yang ditandai dengan berbagai keadaan yang terjadi di bumi ini. Situasi yang terjadi adalah orang-orang merasa cemas terhadap situasi yang terjadi. Yesus, Sang Guru Besar menasehatkan bahwa kecemasan bisa berakibat fatal bagi manusia. Sesuai dengan exegesis yang telah dibuat, bahwa kecemasan mengakibatkan kematian.

Bagi orang percaya, umat Kristus dengan yakin dan percaya yang sungguh dalam iman bahwa akan terjadi masa-masa sulit menjelang akhir zaman sesuai dengan perkataan Yesus. Maka pada saat yang sama, ketika umat Tuhan mengimani akan terjadinya kegoncangan yang akan menimpa bumi ini, maka muncul perasaan cemas, bahkan cemas yang berlebihan.

Pandemi covid-19 dipercayai sebagian umat kristiani sebagai penggenapan nubuatan tentang akhir zaman. Pandemi covid-19 memberikan suatu tanda bahwa sedang berada pada fase akhir zaman dan akan menghadapi kesusahan masa akhir zaman (Simon et al., 2021). Maka dengan demikian Lukas.21:26 memiliki implikasi yang erat terhadap timbulnya kecemasan bagi umat Tuhan.

Kecemasan yang muncul dengan sangat, akan mendorong untuk membuat umat yang percaya dan beriman sepenuhnya pada Yesus akan semakin tekun berdoa untuk memohon perlindungan dan penyertaan Tuhan. Di satu sisi, apabila iman dan kepercayaannya kurang maka ini akan melemahkan baik fisik, mental 
ataupun spiritual, sebab tidak bisa mengontrol kecemasan dengan baik sehingga akan terjadi reaksi-reaksi kimia tubuh yang bisa merapuhkan tubuh.

\section{Kesimpulan}

Perkataan Tuhan Yesus dalam Lukas. 21:26 mengenai kecemasan yang bisa mengakibatkan kematian dapat dibuktikan secara ilmiah dengan benar. Apabila kecemasan yang muncul pada diri seseorang tidak teratasi dengan baik, maka secara fisik akan mendorong nafas bekerja dengan lebih cepat, dan apabila masih belum dapat diatasi dengan baik, maka menurut pengertian dari Lukas. 21:26 nafas yang cepat akan berubah menjadi nafas yang berat atau susah nafas, sehingga mengakibatkan gagal nafas yang berefek pada gagal jantung, sehingga adanya keterpisahan nafas hidup itu.

Proses yang sama terjadi pada orang yang terinfeksi virus corona, dimana virus ini masuk kedalam tubuh akan menginfeksi saluran pernafasan. Maka imun tubuh sebagai tentara tubuh akan meresponnya dengan membentuk sistem kekebalan tubuh. Apabila kecemasan terus menerus tanpa berhenti, maka sistem imun tubuh akan melemah, sehingga imun tubuh tidak dapat melawan virus yang masuk sehingga bisa mengakibatkan hal yang fatal yaitu kematian. Dalam hal ini terlihat jelas sekali keterkaitan antara kecemasan dengan covid-19 sesuai dengan perkataan Tuhan Yesus, bahwa kecemasan bisa mengakibatkan kematian dengan fakta kasus covid-19.

\section{Referensi}

Aidah, S. nur. (2020). Sistem Imunitas Manusia. Penerbit KBM Indonesia.

Ambesa, S. O. S. (2020). Penyakit Dan Kelaparan: Telaah Perkataan Yesus Dalam Lukas 21 : 11 Dan Relevansinya Bagi Gereja Di Masa Pandemi Covid-19. Iegesis: Jurnal Teologi, 5(2), 43-53.

Andrianta, D., Hutagalung, S., \& Ferinia, R. (2020). Kontekstualisasi Ibadah Penghiburan pada Tradisi Slametan Orang Meninggal dalam Budaya Jawa. Visio Dei: Jurnal Teologi Kristen, 2(2), 244-264.

Arini, F. N., Adriatmoko, W., Novita, M., Mulut, B., Gigi, F. K., Jember, U., Forensik, O., Gigi, F. K., \& Jember, U. (2017). Perubahan Tanda Vital sebagai Gejala Rasa Cemas sebelum Melakukan Tindakan Pencabutan Gigi pada Mahasiswa Profesi Klinik Bedah Mulut RSGM Universitas Jember. E-Jurnal Pusat Kesehatan, 5(2), 323-330.

Asrori, A. (2015). Terapi Kognitif Perilaku Untuk Mengatasi Gangguan Kecemasan Sosial. Jurnal Ilmiah Psikologi Terapan (JIPT), 03(01), 89-107.

Chodijah, M., Nurjannah, D. S., Yuliyanti, A. Y., \& Kamba, M. (2020). SEFT Sebagai Terapi Mengatasi Kecemasan Menghadapi Covid-19. In Karya Tulis Ilmiah LPPM UIN Sunan Gunung Djati Bandung.

Ebta Setiawan. (2021). Kamus Besar Bahasa Indonesia - Cemas. Badan Pengembangan Dan Pembinaan Bahasa (Pusat Bahasa).

Eko Meinarno, Maya Khairani, M. M. (2020). Ragam Cerita Pembelajaran dari COVID-19. Syiah Kuala Uiversity Press.

Fakhriyani, D. V., Sa'idah, I., \& Annajih, M. Z. (2021). Pendekatan REBT Melalui Cyber Counseling untuk Mengatasi Kecemasan di Masa Pandemi COVID-19. Counsellia: Jurnal Bimbingan Dan Konseling, 11(1), 56-70. https://doi.org/10.25273/counsellia.v11i1.8463

Fitria, R. (2016). Memahami hermeneutika dalam mengkaji teks. Syi'ar, 16(2), 33-42.

Hutagalung, S. (2020). Interpretasi Teologis :Injil Akan Diberitakan Di Seluruh Dunia Sesudah Itu Barulah Tiba Kesudahan Dalam Matius 24:14 Di Masa Pandemik Covid-19. Koinonia, 12(2), 23-35. 
Juli Andri, Padila, N. A. W. A. (2021). Tingkat Kecemasan Pasien Kardiovaskuler Pada Masa Pandemi Covid-19 Juli. Journal of Telenursing (JOTING), 3(1), 382-389.

Karo, M. B. (2020). Perilaku Hidup Bersih dan Sehat (PHBS) Strategi Pencegahan Penyebaran Virus Covid-19. Prosiding Seminar Nasional Hardiknas, 1(1), 1-4.

Lee, W. (2020). Pelajaran-Hayat Lukas. yayasan Perpustakaan Injil.

Maharani, A. (2013, April). Lima Peristiwa Kelaparan Paling Parah Sejagat. Merdeka.

Makarim, F. R. (2021). Ini Dampak Gangguan Kecemasan Pada Kesehatan Tubuh. Halodoc.

Maryani, S., Netrawati, I. G. A. O., \& Nuada, I. W. (2020). Pendemi Covid-19 dan Implementasinya pada Perekonomian NTB. Jurnal Binawakya, 14(11), 3497-3508.

Meri, Khusnul, Suhartati, R., Mardiana, U., \& Nurpalah, R. (2020). Pemberdayaan Masyarakat Dalam Penggunaan Hand Sanitizier dan Masker Sebagai Upaya Preventif Terhadap Covid-19. Bantenese Jurnal Pengabdian Masyarakat, 2(1), 26-33. https://doi.org/10.30656/ps2pm.v2i1.2340

Meyers, R. (2021). E-Sword. Yayasan Lembaga SABDA.

Muslim, M. (2020). Manajemen Stress pada Masa Pandemi Covid-19" 193. Jurnal Manajemen Bisnis, 23(2), 192-201.

Nagy, G. (2010). The subjectivity of fear as reflected in ancient Greek wording. Dialogues, 5, $29-45$.

Nuraeni, A., \& Mirwanti, R. (2017). Hubungan Cemas Dan Depresi Pada Pasien Dengan Penyakit Jantung Koroner (Pjk). MEDISAINS: Jurnal Ilmiah Ilmu-Ilmu Kesehatan, 15(1), 10-16.

Putri, R. N. (2020). Indonesia dalam Menghadapi Pandemi Covid-19. Jurnal Ilmiah Universitas Batanghari Jambi, 20(2), 705-709. https://doi.org/10.33087/jiubj.v20i2.1010

Santoso, J. (2021). Peran Integrasi Teologi Psikologi Terhadap Pemulihan Perilaku Menyimpang The Role of Psychological Theology Integration Against Deviating Behavior Recovery. SHAMAYIM: Jurnal Teologi Dan Pendidikan Kristiani, 1(2), 174-187.

Sardono, E. E., Hermiawan, N., \& Wekin, O. K. (2020). Makna Fenomena Kematian Massal Di Tengah Pandemi Covid-19 berdasarkan Refleksi Dari Ayub 1:1-22. VISIO DEI: Jurnal Teologi Kristen, 2(2), 265-283.

Satgas Covid-19. (2021). Data Sebaran Covid-19 Nasional. Komite Penanganan Covid-19 Dan Pemulihan Ekonomi Nasional (KPCPEN).

Setyawan, A. B. (2017). Hubungan Tingkat Kecemasan dengan Kualitas Tidur Pasien Pre Operasi diRuang Angsoka Rumah Sakit Abdul Wahab Sjahranie Samarinda. Jurnal Ilmiah Sehat Bebaya, 1(2), 110 116.

Sihombing, R., \& Rundjan, E. (2019). Kajian Tentang Rasa Khawatir Pada Kehidupan "Orang Percaya" Dalam Perspektif Alkitab. Jurnal The Way, 5(1), 70-84.

Simon, Dully, S., Yulianto, T., \& Wibowo, A. P. (2021). Pandemi Covid-19 Dalam Perspektif Teologi Pentakosta. Ritornera - Jurnal Teologi Pentakosta Indonesia, 1(1), 65-77.

Sudarmanto, E., Kurniullah, A. Z., Revida, E., Ferinia, R., Butarbutar, M., Abdilah, L. A., Sudarso, A., Purba, B., Purba, S., Yuniwati, I., Hidayatulloh, A. N., HM, I., \& Suyuthi, N. F. (2021). Desain Penelitian Bisnis: Pendekatan Kuantitatif. Medan:Yayasan Kita Menulis.

Sumakul, N. M. (2020). Pandemi Covid-19 dalam Perspektif Alkitab dan Dampaknya Bagi Kehidupan Manusia. Jurnal Teologi Rahmat, 6(1), 1-12.

Suryani. (2020). Stres Hadapi Coronavirus Picu Turunnya Imunitas Tubuh. Universitas Padjadjaran.

Sutomonaio, T. (2017). Mengaku Sebagai Yesus Kristus, Pria Ini Punya Gaya Hidup dan Pandangan Mengejutkan. Tribun Jabar. 
Syarifuddin. (2019). Imunologi Dasar Prinsip Dasar Sistem Kekebalan Tubuh. Cendekia Publisher.

Tadung, F. P. (2020). Integritas Berperilaku Kudus Berdasarkan 1 Petrus 1:13-25 Terhadap Komitmen Pelayanan Paduan Suara Adonai. Excelsis Deo: Jurnal Teologi, Misiologi Dan Pendidikan, 4(1), 101-115.

Tanjung Subrata et al. (2020). Berlayar Melintasi Badai Covid-19: jaga Kondisi Tanpa Mengabaikan Proteksi. In Fakultas Kedokteran \&Ilmu Kesehatan Universitas Warmadewa. Warmadewa University Press.

Tobing, D. H., Herdiyanto, Y. K., Astiti, D. P., Rustika, I. M., Indrawati, K. R., \& Susilawati, L. K. P. A. (2017). Pendekatan dalam Penelitian Kualitatif. Universitas Udayana.

Wahyono. (2020). 7 Perang Terbesar di Dunia. SindoNews.

Yuansari Octaviana Kansil, M. M. W. (2021). Pendampingan Pastoral Kristiani Bagi Keluarga Yang Berduka Akibat Kematian Karena Covid-19. Poimen : Jurnal Pastoral Konseling, 2(1), 49-65. 